\author{
Tomasz Zwęglińskia)*, Andrii Maksimenko ${ }^{\text {b) }}$, Marcin Smolarkiewicz ${ }^{\text {a) }}$ \\ a) The Main School of Fire Service / Szkoła Główna Służby Pożarniczej \\ b) State Scientific and Research Institute 'Chornobyl Center for Nuclear Safety, Radioactive Waste and Radioecology' \\ Corresponding author / Autor korespondencyjny: tzweglinski@sgsp.edu.pl
}

\title{
Exercising in a Radioactive Environment - a Case Study from CBRNE Exercise in Chernobyl Exclusion Zone
}

\section{Ćwiczenia w środowisku skażonym radioaktywnie - studium przypadku ćwiczeń CBRNE w Czarnobylu w strefie wyłączonej}

\begin{abstract}
Aim: The aim of this paper is to present the results of an experiment which was conducted as a part of the "End-user driven DEmo for cbrNe" (EDEN) project on the 17th and 18th of May 2016 in the Chernobyl Exclusion Zone, and more precisely in Pripyat.

Introduction: One of the main requirements for highly effective emergency exercise is a well prepared and reliable scenario which is executed in conditions that closely resemble reality. This requirement brings even more value if the exercise is tailored to build response capacity for CBRNE hazards. First responders' skills and work experience in contaminated areas are desirable response capacity of emergency units. However, because CBRNE emergencies are low-probability, high-impact events, they are very rarely happening. Therefore, building this response capacity definitely requires exercising, at least in a simulated environment. Simulating CBRNE hazards, and especially biological and radiological ones, is very challenging, expensive, time-consuming, strictly regulated and in many cases, like for nuclear, almost impossible. However, there is one more option, apart from simulating the contamination. It is exercising in contaminated areas like e.g. in the Chernobyl Exclusion Zone. To organise this type of exercise requires from the exercise planners and organizers a deep understanding of the hazard as such. Since the hazard constitutes a realistic risk of negative impact on the exercise participants' health, such events have to be planned and prepared in detail, and with an appropriate consideration given to the risk level in order to minimize it.

An increased level of first responders' readiness built upon such exercises is definitely an operational value. However, it is questioned how high could be the cost of this benefit on the participants health, if any? What are the key aspects to be considered while organising an emergency exercise in a radioactively contaminated training site in order to minimize health and other risks? What type of training and operational benefits could be identified when working in such an environment?

Methodology: The paper analyses the CBRNE exercise executed in Pripyat presenting a lesson learnt which could easily be utilised by the future planners and organisers of such type of exercises.

Conclusions: The experiment proved that providing a safety plan for such an exercise and its proper implementation allows the exercise to be executed in a manner which ensures that the safety levels regulated by law are not exceeded. Exercising in contaminated zones provides an excellent opportunity for the improvement of individual skills and coping capacity of the entire CBRNE system, including standard operating procedures. It is important to note that during well organized and controlled exercises, the risk for health and life of the first responders due to radioactive contamination and exposure is negligible. Keywords: ionising radiation, effective dose, CBRNE, civil protection exercises
\end{abstract}

Type of article: case study

Received: 20.11.2019; Reviewed: 08.12.2019; Accepted: 17.12.2019;

Authors' ORCID IDs: T. Zwęgliński - 0000-0003-2652-8068; A. Maksimienko - 0000-0001-5380-2312; M. Smolarkiewicz - 0000-0002-5681-2548;

Percentage contributon: T. Zwęgliński - 40\%; A. Maksimienko - 30\%; M. Smolarkiewicz - 30\%;

Please cite as: SFT Vol. 54 Issue 2, 2019, pp. 160-166, https://doi.org/10.12845/sft.54.2.2019.12;

This is an open access article under the CC BY-SA 4.0 license (https://creativecommons.org/licenses/by-sa/4.0/).

\section{ABSTRAKT}

Cel: Celem artykułu jest przedstawienie wyników eksperymentu przeprowadzonego w dniach 17 i 18 maja 2016 r. w ramach projektu „End-user driven DEmo for cbrNe" (EDEN) w Czarnobylskiej Strefie Wykluczenia, w Prypeci.

Wprowadzenie: Warunkiem skutecznych ćwiczeń ratowniczych jest dobrze przygotowany i niezawodny scenariusz, realizowany w warunkach bardzo zbliżonych do rzeczywistych. Przeprowadzone w ten sposób ćwiczenia mają jeszcze większą wartość, jeśli uwzględniają budowanie zdolności do reagowania na zagrożenia CBRNE. Umiejętności i doświadczenie służb ratowniczych w działaniach na obszarach skażonych mają istotne znaczenie z punktu widzenia zdolności ratowników do reagowania. Ponieważ jednak awarie CBRNE są zdarzeniami o niskim prawdopodobieństwie i dużym wpływie, zdarzają się bardzo rzadko. W związku z tym budowanie zdolności do reagowania na tego typu incydenty bez wątpienia wymaga ćwiczeń, przynajmniej w symulo- 
wanym środowisku. Symulowanie zagrożeń CBRNE, szczególnie tych biologicznych i radiologicznych, jest nie tylko bardzo trudne, drogie, czasochłonne i ściśle regulowane, ale w wielu przypadkach - np. zagrożeń nuklearnych - prawie niemożliwe. Poza symulowaniem skażeń istnieje jednak jeszcze jedno rozwiązanie. Jest nim prowadzenie ćwiczeń na skażonych obszarach, takich jak np. Czarnobylska Strefa Wykluczenia. Zorganizowanie tego rodzaju ćwiczeń wymaga głębokiego zrozumienia samego zagrożenia, stanowi ono bowiem realne ryzyko dla zdrowia uczestników szkolenia. Tego rodzaju ćwiczenia powinny być zaplanowane i szczegółowo przygotowane. Należy uwzględnić poziom ryzyka, aby można było je odpowiednio zminimalizować. Zwiększenie poziomu gotowości ratowników stanowi istotną korzyść operacyjną. Jakie są zatem zagrożenia zdrowotne dla ćwiczących ratowników, jeśli w ogóle one występują? Jakie są kluczowe aspekty organizacyjne, które należy wziąć pod uwagę podczas tego rodzaju ćwiczeń celem zminimalizowania ryzyka (w tym zdrowotnego)? Jakiego rodzaju korzyści o charakterze szkoleniowym i operacyjnym można zidentyfikować podczas takich ćwiczeń? Metodologia: W artykule przeanalizowano ćwiczenia CBRNE przeprowadzone w Prypeci. Przedstawiono wnioski, które mogą być wykorzystywane przez przyszłych pomysłodawców i organizatorów tego rodzaju ćwiczeń.

Wnioski: Eksperyment wykazał, że opracowanie planu bezpieczeństwa dla takiego ćwiczenia i jego właściwe wdrożenie pozwalają na realizację przedsięwzięcia z zachowaniem poziomu bezpieczeństwa uregulowanego przepisami prawa. Ćwiczenie w strefach skażonych stanowi doskonałą okazję do doskonalenia indywidualnych umiejętności i zdolności radzenia sobie w zdarzeniach CBRNE, w tym w zakresie standardowych procedur operacyjnych. Należy podkreślić, że podczas dobrze zorganizowanych i kontrolowanych ćwiczeń ryzyko dla zdrowia i życia uczestników z powodu skażenia i narażenia na promieniowanie jest znikome.

Słowa kluczowe: promieniowanie jonizujące, skuteczna dawka, CBRNE, ćwiczenia z zakresu ochrony ludności

Typ artykułu: studium przypadku

Przyjęty: 20.11.2019; Zrecenzowany: 08.12.2019; Zatwierdzony: 17.12.2019;

Identyfikatory ORCID autorów: T. Zwęgliński - 0000-0003-2652-8068; A. Maksimienko - 0000-0001-5380-2312; M. Smolarkiewicz-0000-0002-5681-2548;

Procentowy wkład merytoryczny: T. Zwęgliński - 40\%; A. Maksimienko - 30\%; M. Smolarkiewicz - 30\%;

Proszę cytować: SFT Vol. 54 Issue 2, 2019, pp. 160-166, https://doi.org/10.12845/sft.54.2.2019.12;

This is an open access article under the CC BY-SA 4.0 license (https://creativecommons.org/licenses/by-sa/4.0/).

\section{Introduction}

Intentional or unintentional use of hazardous materials, like chemical, biological, radiological, or nuclear materials, or explosives (CBRNE), for the purposes of criminal, terrorist or military acts, is an increasing risk for society. This fact is confirmed by a number of international and national legal regulations, normative acts and strategic documents [1-3]. Moreover, such incidents often tend to be multi-hazard risks including different type of agents and/ or techniques used by the perpetrators at the same time or one after another. Since each state is responsible for providing security for people staying on its territory [4], the increasing risk of CBRNE threats requires high level of engagement from politicians, crisis managers and first responders to develop the coping capacity for this kind of incidents. Coping capacity is understood as "the ability of people, organizations and systems to manage adverse conditions, risk or emergencies using any available skills and resources" [5]. It requires continuing awareness, resources, good management and inter-agency cooperation [6], both in normal times as well as during emergencies or adverse conditions. Coping capacity should obviously contribute to a reduction in CBRNE risks.

Building resilience always starts with understanding a hazard and a risk which the hazard could generate when materialised. Therefore, it is highly relevant to present the findings produced during the authors' radiological hazard exercise. The nuclear threat is continuously being surveyed to provide a broader and deeper understanding of its impact on human beings and the environment. Fukushima and Chernobyl incidents [7] are the two most recognisable cases which are still being researched to help understand this impact in the best possible way.

Developing coping capacity includes first responder training and exercising of a given risk response. It has been well proven that for an exercise to be highly effective it needs to be run according to a scenario which is as close to real conditions as possible [8-9].
In the case of CBRNE, this raises a lot of doubts. In most cases it literally means exercising in an actually contaminated area. Having said that, it is worth underlining that for chemical and biological agents it is possible to effectively protect first responders with appropriate personal protective equipment (PPE). However, for a radiological hazard, such as neutron and gamma radiation, it is hardly possible to protect them fully, even using PPE. This raises the question of what type of measures should be undertaken in preparation and execution of an exercise being conducted in radioactively contaminated zones in order to minimize the risk of potential negative health effects, while at the same time increasing the first responders' operational readiness for CBRNE incidents.

\section{Methodology}

The experiment was conducted as a part of the "End-user driven DEmo for cbrNe (EDEN)" project, carried out under the European $7^{\text {th }}$ Framework Programme, (EC Grant Agreement 313077). It was conducted on 17 $7^{\text {th }}$ and 18th May 2016 in the Chernobyl Exclusion Zone, in the town of Pripyat. A total of 56 participants from 11 European countries took part in a two-day long emergency exercise. Considering the nature of contamination in the exercise area, radiation protection activities focused on the protection of the participants against the following risks:

- gamma and beta external exposure;

- internal exposure via inhalation and oral paths due to possible formation of dust and airborne particles in breathing zone during the decontamination activities and use of quadcopters, robotic equipment, etc.;

- radioactive contamination of skin surface;

- radioactive contamination of personal belongings and equipment. 
There were also some activities preventing the aggravation of radiation conditions within the exercise area and transfer of radioactive contamination outside the site.

To minimize the risk of alpha radiation (internal exposure), and radioactive contamination of skin surface and personal belongings and equipment, the participants had been recommended to use protective clothing. It was a set composed of a jumpsuit with a hood, overshoes (personal protective clothes - type 5, confirmed by the European standards EN 13982, EN 1073-2, EN 11495), nitrile gloves (thickness $=0.12 \mathrm{~mm}$ ), plastic glasses and, as a minimum, a half mask with respirator FFP1 protection class (filtration efficiency $80 \%$, confirmed by the European standard EN 149) with a respirator (Figure 1). In order to increase the participants' safety level above the minimum standard described in the previous sentence, ultimately during the exercise the participants used a half mask with respirator RP A-200 П-3K - FFP-3D protection class (filtration efficiency $99 \%$, EN 149), instead of FFP1. Moreover, for safety and measurement purposes, they were equipped with individual thermoluminescent dosimeters - TLD and electronic dosimeter - ED (Polimaster PM 1610, confirmed by the European standards EN 61326-1:2013, EN 61326-2-2:2013, EN 61000-6-2:2005, EN 61000-6-3:2007+A1:2011, EN 55022:2010), calibrated annually, measuring gamma effective doses to which the participants were exposed. The total time period of the exercise, which means the participants' presence in the contaminated area, was $16 \mathrm{hrs} 58 \mathrm{~min}$. Since all of the participants were appropriately protected from the internal irradiation (inhalation), the irradiation effective dose was calculated only from the external gamma radiation. The individual effective gamma doses for each exercise participant, for two days exposure, were measured. The total effective gamma doses for each participant were compared with effective dose rates set in legal regulations.

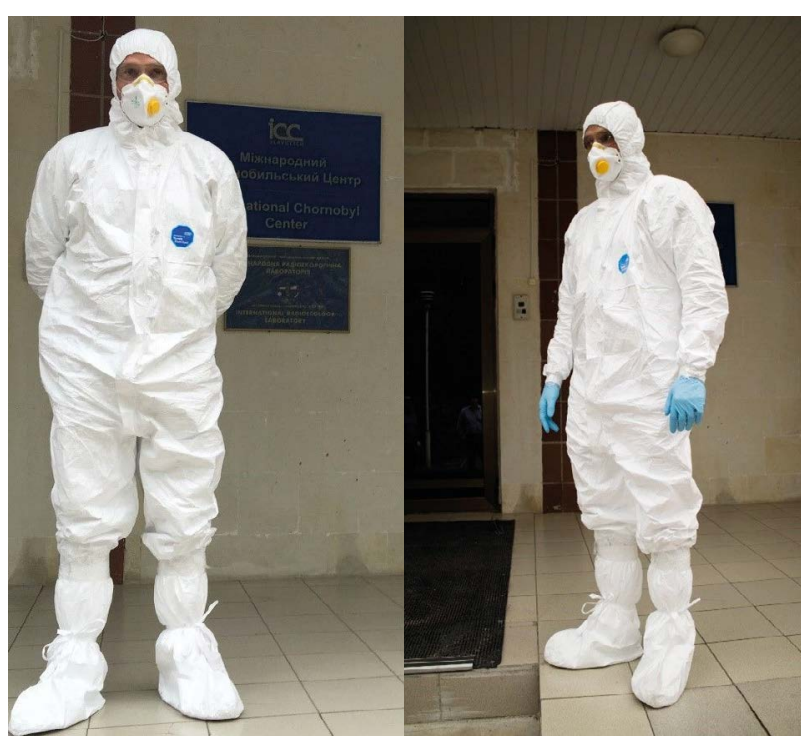

Figure 1. Recommended minimal PPE for the participants and staff of the Pripyat exercise held in May 17-18, 2016 in the Chernobyl Exclusion Zone Source: Own elaboration based on Hotzone Solutions, Safety requirements for the work in the Chernobyl exclusion Zone on a large scale exercise, HZS, 2016, [10].
The main sources of contamination nowadays in the Chernobyl Exclusion Zone are ${ }^{90} \mathrm{Sr}$ and ${ }^{137} \mathrm{Cs} .{ }^{90} \mathrm{Sr}$ contamination generally correlates with ${ }^{137} \mathrm{Cs}$. The most serious contamination is associated with the northern trace and western sub-latitudinal trace (its narrowest "explosive" zone). Maximal surface contamination within 2-5 km around the Chernobyl Nuclear Power Plant reaches 18 to $40 \mathrm{MBq} / \mathrm{m}^{2}$, decreasing to $400-1100 \mathrm{kBq} / \mathrm{m}^{2}$ as the distance grows to $30 \mathrm{~km}$. Near Chernobyl the contamination is $200 \mathrm{kBq} / \mathrm{m}^{2}$, and over the peripheral part of the $30-\mathrm{km}$ zone it is $40-200 \mathrm{kBq} / \mathrm{m}^{2}$, reaching $100-200 \mathrm{kBq} / \mathrm{m}^{2}$ along its northern border (Figure 2).

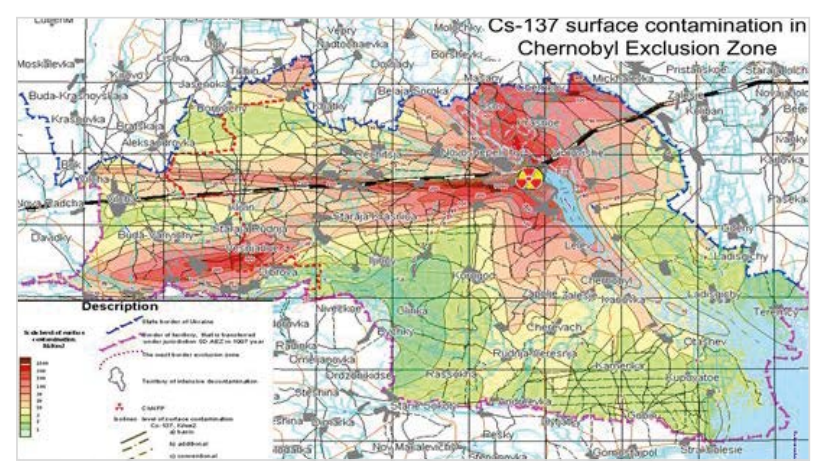

Figure 2. Contamination of the Chernobyl Exclusion Zone by ${ }^{137} \mathrm{Cs}$

Source: S. P. Gashchak, M. D. Bondarkov, Y. I. Ivanov, A. M. Maksymenko, V.I. Martynenko, A. N. Arkhipov, Radioecology of urban landscape through the example of the town of Pripyat. Problems of the Chornobyl exclusion zone, IAEA 2009, [11].

Previous aero-gamma survey of Pripyat showed contamination level with ${ }^{137} \mathrm{Cs}$ from 10 to $300 \mathrm{Ci} / \mathrm{km}^{2}\left(370,0 \mathrm{GBq} / \mathrm{km}^{2}\right.$ - 11,1 TBq/ $/ \mathrm{km}^{2}$ ) (Figure 3).

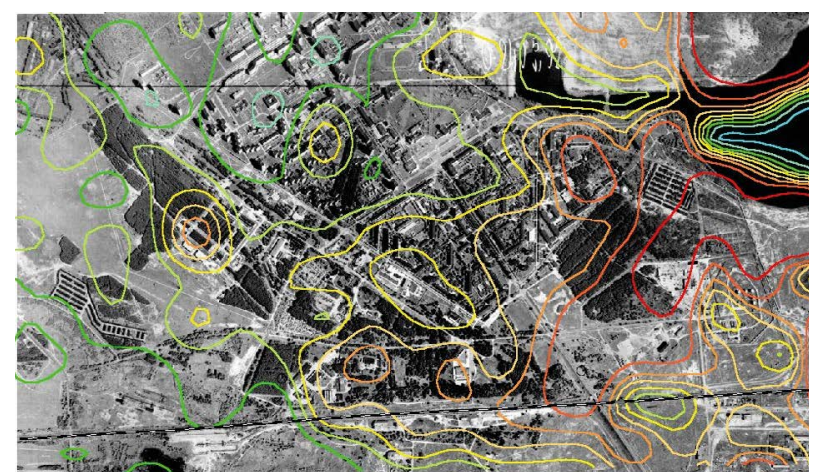

Figure 3. Density of the Pripyat area contamination with ${ }^{137} \mathrm{Cs}$, as per the results of aero-gamma survey of 1992 (colour scale from light blue [10 Ci/ $\left.\mathrm{km}^{2}=370,0 \mathrm{GBq} / \mathrm{km}^{2}\right]$ to red $\left.\left[300 \mathrm{Ci} / \mathrm{km}^{2}=11,1 \mathrm{TBq} / \mathrm{km}^{2}\right]\right)$.

Source: State Scientific and Research Institution 'Chornobyl Centre for nuclear safety, radioactive waste and radioecology', Report on the provision of services under contract No. 0209/2015, Ukraine, 2015, [12].

The exercise area was located in the south-east part of Pripyat, as presented in Figure 4 (red line - administrative border of the town, blue line - exercise site).

There are seven areas with high levels of gamma radiation - red spots - and three areas with low levels of gamma radiation - green rectangles located within the exercise site (Figure 5). 


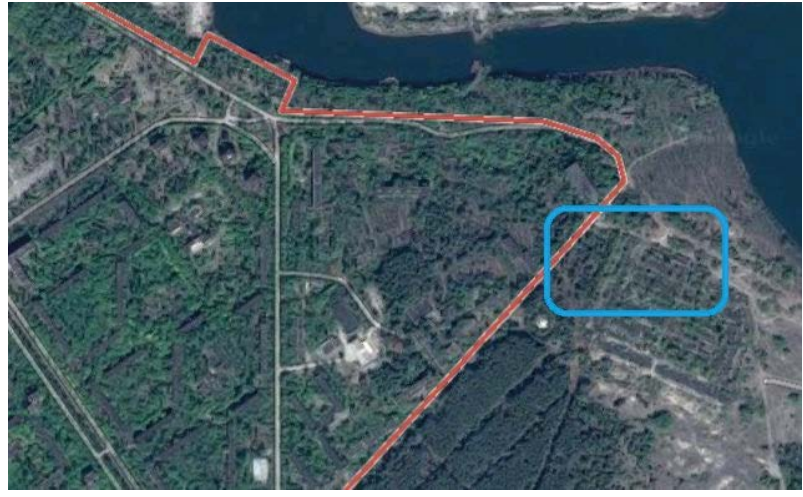

Figure 4. Exercise area marked in a satellite picture of Pripyat Source: Own elaboration based on State Scientific and Research Institution 'Chornobyl Centre for nuclear safety, radioactive waste and radioecology', Report on the provision of services under contract No. 0209/2015, Ukraine, 2015, [12]

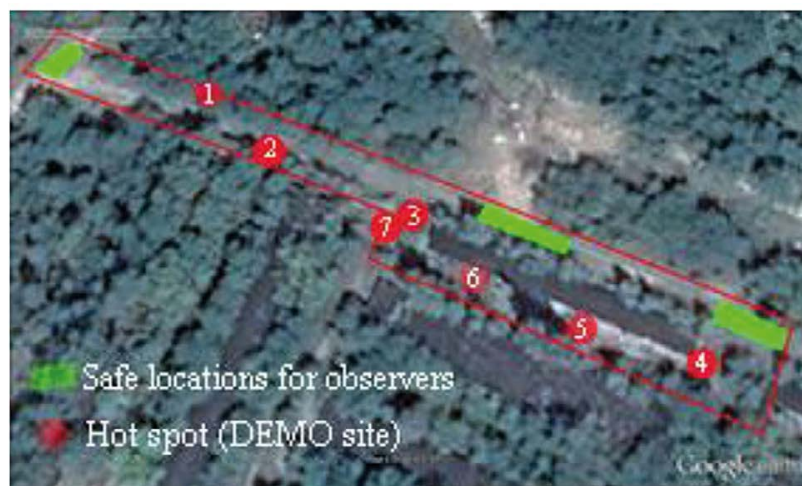

Figure 5. Location of the gamma 'hot spots' within the Pripyat exercise area. Source: State Scientific and Research Institution 'Chornobyl Centre for nuclear safety, radioactive waste and radioecology', Report on the provision of services under contract No. 0209/2015, Ukraine, 2015.No. 0209/2015, Ukraine, 2015, [12].

The seven hot-spots had been measured before the exercise during the preparatory phase and the results were as follows: 1) 27.7 ; 2) 19.3 ; 3) 25.6 ; 4) 47.0 ; 5) 11.2 ; 6) 11.2 ; 7) $20.2 \mu \mathrm{Sv}-\mathrm{h}^{-1}$.

Furthermore, six months prior to the exercise, a detailed measurement was conducted in order to map the dose rate coverage within the entire exercise site (Figure 6).

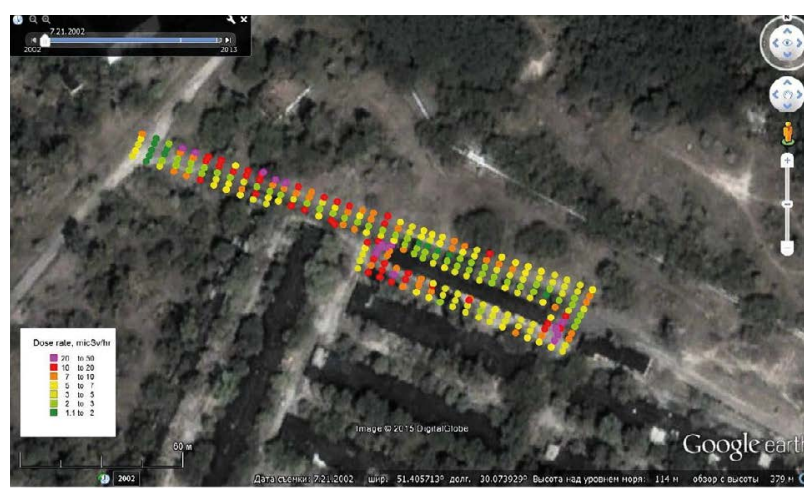

Figure 6. Dose rates (micSv/hr) measured in the Pripyat exercise area in 2016. Source: State Scientific and Research Institution 'Chornobyl Centre for nuclear safety, radioactive waste and radioecology', Report on the provision of services under contract No. 0209/2015, Ukraine, 2015, [12].
The measurements of individual effective gamma doses were conducted while the participants were working within the Pripyat exercise site (Figure 7).

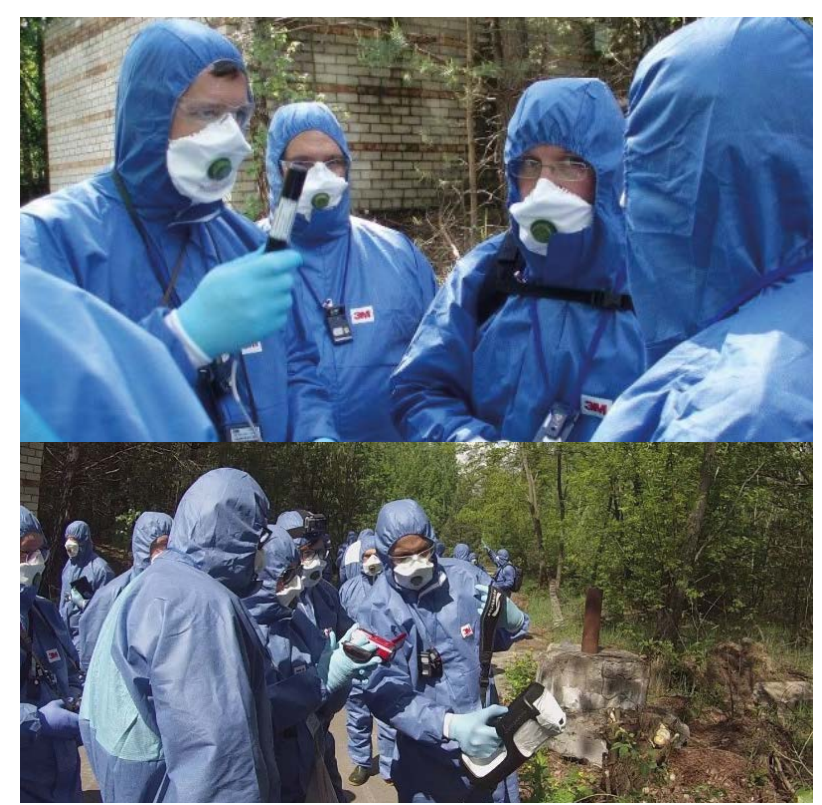

Figure 7. Measurements and testing of new solutions in the Pripyat area - an exercise conducted as part of the EDEN Project

Source: Own elaboration based on Project "End-user driven DEmo for cbrNe (EDEN)", Report: D65.8 - Evaluation Report of the RN Demonstration, European Commission, 2016, [13].

\section{Results and discussion}

The authors measured the individual effective gamma doses to which each participant of the exercise was exposed. This was done during the first day of the exercise $\left(E_{1}\right)$ with an error $\delta E_{1}=0.001 \mathrm{mSv}$, and during the second day of the exercise $\left(E_{2}\right)$ with an error $\delta E_{2}=0.01 \mathrm{mSv}$. The total effective gamma dose for the two days was calculated (ET $\pm \delta E T$ ), with $0.041 \pm 0.011 \mathrm{mSv}$ as the lowest result, and $0.094 \pm 0.011 \mathrm{mSv}$ as the highest result.

Taking into account international and Polish [14] regulations, the doses admitted by the participants of the exercise were far lower than the limits allowed by the legal regulations. According to Polish regulations, which are based on international acts, a yearly dose limit for a member of the public is $1 \mathrm{mSv}$. Therefore, it is reasonable to conclude that the average effective dose to which the group of the exercise participants was exposed constituted only $6.3 \%$ of the yearly accepted dose for such a person. If we consider that the Polish limit for a person having contact with radiation during regular work is $20 \mathrm{mSv}$ ( $50 \mathrm{mSv}$ in USA regulations), the average amount absorbed during the exercise constitutes only $0.315 \%$ for Polish regulations $(0.126 \%$ for USA). Comparing the average absorbed dose with other limits regulated by law, it is worth mentioning that for workers or rescuers acting in a radioactive environment in the event of a life rescue operation the effective dose limit is $500 \mathrm{mSv}$. Therefore, the average dose absorbed during the exercise was only $0.013 \%$ of that limit. 
Standard deviation for the doses measured during the two days is 0.011 , while median is the same as the average dose (0.063). This means that the number of the measurements above and below 0.063 is the same, so there are no measurements which significantly differ from the others. It proves good supervision of the participants by the exercise staff and following of the instructions given to the participants in order to avoid any not reasonably acceptable irradiation e.g. by going out of the exercise site. The Pearson correlation factor shows that the measurements from the $1^{\text {st }}$ day are slightly positively correlated with the measurements taken on the $2^{\text {nd }}$ day. This could lead to a conclusion that the behaviour of the individuals was in line with the appropriate level of the safety instructions during both days of the exercise.

It is quite clear that the doses absorbed by the exercise participants during these several hours are fully acceptable exposures from the legal point of view. It should be underlined that the movement of the participants was mainly along asphalt routes, very rarely through bushes or other potentially more contaminated areas. Since the hot spots, as described above, were clearly marked, the participants were careful not to come too close or for too long to those locations in order to complete the exercise tasks.

There is a number of recommendations formulated on the base of the experiment. All of them could facilitate the work of specialists organising exercises in contaminated zones. They are as follows:

1. Due to the contaminated zone and safety measures consider a limited number of participants to have appropriate control over their movement.

2. Make prior preventing measures which are specific for contaminated zones, such as: creating a current map of contamination within the exercise site, appointing and marking main routes for safe movement (the best would be asphalt routes), sprinkling the routes with water to limit contamination, covering with plastic film the areas in which the organizational staff foresee a longer stay of people not directly involved in the exercise e.g. observers, etc.

3. In order to keep the exposure of its participants as low as reasonably acceptable (ALARA), limit the time of the exercise to a practical minimum enabling completion of the exercise objectives.

4. Recommend each participant to undergo a medical examination prior to the exercise to confirm that he/she does not have medical contraindications for working with ionising sources, wearing respiratory protective equipment, etc. [15]

5. Any real emergency during the exercise requires the injured personnel to be checked for contamination followed by decontamination measures, if needed.

6. Control the individual dose of the participants' external exposure, as necessary to carry out both routine monitoring using thermoluminescent dosimeters (TLD) and task related monitoring using electronic dosimeters (ED) [16].

7. An opportunity for simulating causalities or fatalities during the exercise is limited only to safe locations with reasonable levels of contamination, in order to avoid any unacceptable health risks; an alternative option could be using mannequins.

8. Receive all the formal permissions to run the exercise from the authority legally administrating the site; this is especially important due to the uncertainty related to the political situation in Ukraine.

9. Consider the limited access to GSM network; e.g. in Chernobyl, the area has been abandoned for more than 30 years, so new technologies or systems are generally not available there. For exercise purposes, this could be solved by installing satellite Internet (this was done in the case of the analysed exercise) - the usefulness of the satellite-based information systems for crisis management is broadly recognised and was already discussed e.g. by [17].

10. Check any used equipment and clothing for contamination in order to avoid spreading contamination outside the contaminated zone. In the case of the Chernobyl Exclusion Zone, it is required to check the staff on some checkpoints, and if the equipment cannot be decontaminated, it will have to be left in the zone. This rises the risk of leaving expensive equipment in the zone after the exercise (after the analysed exercise, some pieces of equipment - wheels of an unmanned ground vehicle (UGV) - had to be left in the exercise site). If not appropriately checked, the equipment could be stopped also on the border of the country after it is checked for radiation by border guards.

11. Impossible to use tents for accommodation overnight in the event of a long exercise due to a not reasonably acceptable risk of exposure.

12. Keep specific precautions concerning the behaviour in the exclusion zone e.g. no eating, no smoking, etc.

13. Eat only in safe places like e.g. canteens - this causes logistical and time management problems during the exercise.

All these arrangements require professional management and heavy workload during all phases of the exercise, and especially in the preparatory phase. So, what type of operational benefits were identified for exercising in contaminated sites? These are listed below:

1. Checking standard operating procedures such as radiological hazard detection and source identification is a key aspect in any CBRNE response. Testing them in real conditions is obviously more valuable and reliable than in a simulated environment;

2. Checking detectors and other measurement devices in real conditions is a unique opportunity due to the fact that it is very difficult to simulate or create radiation higher than the background radiation in non-contaminated areas e.g. because of legal restrictions.

3. Checking procedures for putting on and taking off personal protective equipment (PPE) in conditions which enable testing contamination level on and under the PPE. It could help identify any faulty elements of the procedures or mistakes made by practitioners. 
4. Checking person and equipment decontamination measures with ad hoc verification of their effectiveness e.g. by measurements done after decontamination.

5. Checking electronic devices being part of the equipment and their functioning parameters in the radioactive environment.

6. Contamination is a part of the exercise site, therefore simulation of this is not needed any more, and the site is as realistic as it can be.

7. Working in contaminated zones brings additional psychological pressure on first responders, and operational and tactical decision makers, which allows testing and improving their skills related to working under mental pressure of a real incident.

8. Working in a contaminated site helps understand radioactive contamination characteristics, including very variable distribution of the radioactive sources in the area, small distances can make a big difference in contamination, different types of ground coverage (bushes, roads, buildings, etc.) generate different levels of radiation, etc.

9. Due to the fact that there are not too many radioactively contaminated areas in the world, generally such exercises require working in an international environment, with foreign practitioners and experts. This brings added value in the sense of networking that could be highly useful in real emergencies and if there is ever a need for international assistance.

\section{Conclusions}

Organization of a CBRNE exercise is a complex and complicated challenge. Things start to be even more challenging when we realize the exercise is to be conducted in a contaminated area. But such exercises can be far more beneficial from the training perspective.

The two-day long experiment in Pripyat proved that providing a safety plan for such an exercise and its proper implementation, including the use of appropriate PPE and compliance with strict safety rules, guarantees acceptable safety level of everyone involved. This approach generates a win-win situation. First responders can benefit from a realistic environment for exercising purposes with taking a reasonably acceptable risk of exposure to ionising radiation. Exercising in contaminated areas provides an excellent opportunity to improve individual skills of first responders and coping capacity of entire CBRNE systems e.g. by testing and reinforcing standard operating procedures. Finally, it is important to highlight that with a well organised and controlled exercise, the risk from radioactive contamination and exposure for the health and life of the first responders and other involved persons could be negligibly small.

This Project "End-user driven DEmo for cbrNe" (EDEN) was funded by the European Union Seventh Framework Programme under Grant Agreement No. 313077 and co-founded by the Polish Ministry of Science and Higher Education, Decision No. 2962/7.PR/13/2014/2.

\section{References}

[1] UN Security Council Resolution S/RES/1540, UN Office for Disarmament Affairs, 2004.

[2] European Commission, EU CBRN Action Plan to enhance preparedness against chemical, biological, radiological and nuclear security risks, EU Commission, Brussels, 2017.

[3] Polish Government Centre for Security (RCB), Polish National Crises Management Plan, Part A, RCB.

[4] Zwęgliński T., Analiza polityczno-administracyjnych procesów decyzyjnych Unii Europejskiej w przypadku wystąpienia międzysektorowych i transgranicznych sytuacji kryzysowych, in: Koncepcje $i$ instrumenty zarządzania w administracji publicznej, [ed.] Gołębiowska A., Warsaw, Publishing House CIP - Polish National Library, Chancellery of the Polish Senate, 2017, 37.

[5] UN Office for Disaster Risk Reduction, Report of the Open-ended intergovernmental expert working group on indicators and terminology relating to disaster risk reduction, UN DRR, 2016.

[6] Zwęgliński T., Morgado C., Analytical approach to cooperation of the State Fire Service with the Police in Poland in the context of brief comparison with Portuguese reality, "Internal Security" 2018, 10(2), 161.

[7] Imanaka T., Hayashi G., Endo S., Comparison of the accident process, radioactivity release and ground contamination between Chernobyl and Fukushima-1, "Journal of Radiation Research" 2015 56(1), 56-61, https://doi. org/10.1093/jrr/rrv074.

[8] Handbook Evaluation of Exercises, MSB244, Mars: Swedish Civil Contingencies Agency, 2011, 36.

[9] Beerens R. J. J. and Tehler H., Scoping the field of disaster exercise evaluation - A literature overview and Analysis, "International Journal of Disaster Risk Reduction" 2016, 19, 419, https://doi.org/10.1093/jrr/rrv074.

[10] Hotzone Solutions, Safety requirements for the work in the Chernobyl exclusion Zone on a large scale exercise, HZS, 2016.

[11] Gashchak S. P., Bondarkov M. D., Ivanov Y. I., Maksymenko A. M., Martynenko V. I., Arkhipov A. N., Radioecology of urban landscape through the example of the town of Pripyat. Problems of the Chornobyl exclusion zone, IAEA 2009.

[12] State Scientific and Research Institution 'Chornobyl Centre for nuclear safety, radioactive waste and radioecology', Report on the provision of services under contract No. 0209/2015, Ukraine, 2015.

[13] Project "End-user driven DEmo for cbrNe (EDEN)", Report: D65.8 - Evaluation Report of the RN Demonstration, European Commission, 2016.

[14] Regulation of the Polish Council of Ministers of 18 January 2005 on the limit dose of ionising radiation (Journal of Law 2005 no. 20 pos. 168). [Rozporządzenie Rady Ministrów z dnia 18 stycznia 2005 r. w sprawie dawek granicznych promieniowania jonizującego (Dz.U. $2005 \mathrm{Nr}$ 20, poz. 168)].

[15] International Atomic Energy Agency, International Labour Office, Occupational radiation protection, safety guide series No. RS-G-1.1, IAEA, Vienna 1999. 
[16] International Atomic Energy Agency, International Labour Office, Assessment of occupational exposure due to external sources of radiation, safety guide series No. RS-G-1.3, IAEA, Vienna 1999.
[17] Ryzenko J., Smolarkiewicz M. M., Space-enabled information environment for crisis management. Scenario-based analysis and evaluation in an operational environment, "Acta Astronautica" 2010, 66, 33-39, https://doi. org/10.1016/j.actaastro.2009.03.088.
TOMASZ ZWĘGLIŃSKI, PH.D. - professional fire officer (Lt. Col.) and specialist in civil protection and crisis management. An academic and the Director of the Internal Security Institute at the Main School of Fire Service (Warsaw, Poland). He got his Ph.D. from the Military National Defence Academy in Warsaw (Poland) in the scientific discipline of Security Sciences. He studied fire engineering and crisis management at the Main School of Fire Service (Warsaw, Poland), respectively at the Fire Safety Engineering Faculty and Civil Safety Engineering Faculty. As an occupational safety expert, he graduated from the Warsaw Technical University and Central Institute for Labour Protection - National Research Institute in Poland. He is a high level coordination expert of the European Union Civil Protection Mechanism and a natural disaster expert of Joint Environmental Unit UNEP/OCHA. In 2018, he became a EU CBRN Security Manager by completing an international post-graduate course financed from the EU Internal Security Fund.

ANDRII MAKSIMENKO - Deputy Director General of State Scientific and Research Institution 'Chornobyl Center for Nuclear Safety, Radioactive Waste and Radioecology' (Slavutych, Ukraine). He graduated as Chemical Engineer from the Sevastopol Institute of Nuclear Energy and Industry. He earned his Bachelor of Chemical Engineering and Technology from the Sevastopol Higher Naval Engineering School.
MARCIN SMOLARKIEWICZ, ASSOC. PROF. - in 1998, he graduated from the Faculty of Physics, University of Warsaw. In 2003, he was awarded the title of Doctor of Physical Sciences in the specialization of nuclear physics. In 2014, he received a post-doctoral degree in social sciences in the discipline of defence sciences (dissertation on "The theory of associated matrices and $\mathrm{N}$-dimensional safety matrix - new template methods for crisis management") at the Faculty of Management and Command of National Defence University in Warsaw. Since 2001, he has been employed at the Main School of Fire Service (SGSP) as an assistant, and since 2003 as an Assistant Professor, from 01.07.2005 to 29.02.2008 as the Head of the Educational Centre of Public Safety. Currently, he holds the position of Associate Professor at the Main School of Fire Service. $\mathrm{He}$ is the author of over forty national and international publications (including monographs) and a leader of scientific projects in the fields of safety, crisis management, risk analysis and the role and methods of using information systems in safety and security. 